\title{
IMPLEMENTASI METODE K-MEANS UNTUK KLASTERISASI LAHAN PERTANIAN STRAWBERRY DI DAERAH SUBANG BERBASIS IoT(INTERNET OF THINGS) MENGGUNAKAN PLATFORM NODE-RED
}

\author{
Usep Tatang Suryadi*1, Rima Selviani. ${ }^{* 2}$
}

Program Studi Teknik Informatika, STMIK Subang

Jl. Marsinu No. 5 - Subang, Tlp. 0206-417853 Fax. 0206-411873

E-mail: giemuhammad@yahoo.com ${ }^{* 1}$, selvianirima04@gmail.com ${ }^{\# 2}$

\begin{abstract}
ABSTRAKS
Tingkat keasaman, kelembaban dan suhu udara pada tanah berpengaruh besar dalam pertumbuhan tanaman strawberry maka dari itu sangat dibutuhkan sebuah alat untuk mengetahui tingkat keasaman, kelembaban tanah ditambah suhu udara dan sistem klasterisasi tanah pertanian yang cocok untuk tanaman strawberry agar bisa dijadikan rujukan dalam merekomendasikan daerah mana saja yang cocok ditanami strawberry di lahan pertanian para petani di Daerah Subang.

Data-data yang diproses oleh sistem didapatkan dari penelitan langsung ke lapangan dan pengambilan sampel tanah ke setiap titik daerah yang sudah ditentukan oleh penulis dengan berbagai pertimbangan mulai dari jenis dataran, suhu dan tingkat kekeringan tanahnya, data yang didapatkan adalah hasil dari sensor yang ditanamkan kedalam mikrokontroler dan disambungkan melalui sebuah jaringan hotspot dari smartphone lalu diproses menggunakan algoritma $k$-means clustering sehingga bisa diinputkan kedalam database menggunakan platform node-red. Data yang sudah masuk kedalam database bisa langsung diproses/dihitung dengan metode k-means yang sudah penulis tanamkan di dalam sistemnya, dan hasil akhir dari sistem ini kita bisa melihat hasil klasterisasi dari data yang sudah diproses oleh sistem menjadi 3 klaster dan penulis menggunakan 2 buah board mikrokontroler dan 3 sensor, untuk board mikrokontroler penulis memakai Arduino uno dan Node mcu ESP8266, untuk sensor penulis memakai sensor kelembaban tanah (soil moisture) dari China, sensor pH probel pH tanah, dan sensor suhu (DHT11) produk lokal dari Indonesia.
\end{abstract}

Sistem yang dibangun menghasilkan klaster area pertanian yang cocok untuk budidaya tanaman strawberry.

Kata Kunci: Internet of Things, K-Means Clustering, Node Red, Strawberry.

\section{Pendahuluan}

\subsection{Latar Belakang}

Dari beberapa daerah di Kabupaten Subang ada potensi lahan untuk pengembangan pertanian PJKU di Kabupaten Subang seluruhnya mencakup luas 98.855 ha atau 45,55\% dari luas total Kabupaten, yang terdiri atas lahan basah (sawah) eksisting seluas 91.135 ha dan lahan kering/tegalan seluas 7.720 ha. Lahan potensial tersebut meliputi 30 wilayah Kecamatan (Hikmatullah, et al., 2015). Dengan luasnya potensi lahan ini petani Subang mampu mengembangkan hasil perkebunannya, mereka bisa menghasilkan aneka sayuran dan aneka buah-buahan selain nanas yang menjadi ciri khas kota Subang. Salah satu buah-buahan yang mungkin dikembangkan di daerah Subang adalah Strawberry.

Strawberry memang bukan asli tanaman indonesia, namun ternyata dapat tumbuh dan berkembang di beberapa daerah indonesia di pegunungan yang iklim nya sejuk. Dari situs balitjestro litbang pertanian, Secara umum syarat tumbuh yang baik untuk strawberry yaitu dengan suhu udara 14 - $24^{\circ} \mathrm{C}$, kelembaban $85-95 \%$, penyinaran matahari 8-10 jam/hari, dan PH tanah yang ideal adalah 5.6 - 6.5. Walaupun tanahnya terlihat subur, tidak semua petani bisa menanam strawberry pada lahan pertaniannya karena petani tersebut tidak mengetahui kadar PH dan Kelembaban tanah yang ideal 
untuk menanam strawberry maka dari itu banyak sekali petani yang gagal menanam strawberry karena mereka tidak menguji kelayakan tanah lahan pertaniannya tersebut.

Sebenarnya terdapat metode mengetahui tingkat kecocokan tanah untuk tanaman strawberry dengan mengambil sample tanah pada lahan pertaniannya kemudian diteliti di laboratorium, namun hal ini cukup merepotkan petani. Seiring perkembangan teknologi dalam bidang informatika yang berkembang pesat seperti halnya dalam bidang mikrokontroller untuk memudahkan manusia dalam melakukan berbagai hal dan mendapat informasi yang dibutuhkan termasuk informasi data mengenai kecocokan tanah di daerah dataran sedang atau dataran rendah untuk ditanami Strawberry.

Oleh karena itu, penelitian ini membuat sebuah alat yang mampu mengetahui kecocokan tanah menggunakan parameter $\mathrm{pH}$ tanah, kelembabannya dan kadar suhu udara yang cocok untuk menanam tanaman Strawberry yaitu menggunakan Nodemcu ESP8266, Sensor pH Tanah, Sensor Kelembapan Tanah (Soil Mouisture), Sensor suhu udara(DHT11) dengan menggunakan Platform Node-red yang datanya akan diolah dengan Metode K-Means dan Sistem ini akan berbasis IoT (Internet of Things).

Dengan adanya penelitian ini diharapkan dapat membantu petani, terutama petani di daerah dataran sedang atau dataran rendah untuk mengetahui kesesuaian tanah pada lahan pertaniannya jika ditanami Strawberry.

\subsection{Identifikasi Masalah}

Masalah yang dirumuskan dalam penelitian ini adalah sebagai berikut :

- Belum adanya sebuah sistem untuk klasterisasi lahan pertanian khusus untuk tanaman strawberry daerah subang.

- Dibutuhkan sebuah Alat dan Sistem untuk mengklasterkan tanah berdasarkan pH, kelembaban tanah dan suhu sebagai landasan merekomendasikan daerah mana saja yang bagus ditanami Strawberry.

\subsection{Tujuan}

Tujuan yang diperoleh dari penelitian ini adalah membuat alat dan sistem yang sesuai untuk mengklasterkan lahan pertanian yang cocok ditanami strawberry dengan mengetahui tingkat keasaman, kelembaban tanah dan suhu udara yang kemudian dijadikan sebagai rujukan petani dalam mengolah lahan pertanian mana saja yang ideal ditanami strawberry.

\subsection{Manfaat}

Manfaat yang ingin dicapai pada penelitian ini adalah membantu petani mengetahui kualitas tanah milik lahan pertaniannya dengan parameter tingkat keasaman, kelembaban, serta suhu. Selain itu adapun manfaat lain dari penelitian ini yakni membantu pihak terkait untuk klasterisasi atau pengelompokan lahan pertanian mana saja yang ideal ditanami strawberry khususnya lahan pertanian di daerah Subang sehingga memungkinkan petani di dataran sedang dan dataran rendah ikut menanam atau membudidayakan Strawberry pada lahan pertaniannya.

\subsection{Metodologi Penelitian}

Metode penelitian yang akan digunakan dalam pembuatan sistem penentu keputusan ini adalah metode prancangan perangkat lunak Waterfall. Pengembangan metode Waterfall sendiri melalui beberapa tahapan yaitu:

- Penelitian Lapangan (Field Research), Penelitian dilakukan langsung turun kelapangan untuk mendapatkan data dan informasi yang dibutuhkan.

- Penelitian Kepustakaan (Library Research), Penelitian ini bertujuan untuk mendapatkan data yang bersifat teori seperti mengumpulkan buku-buku atau bahan lainnya.

- Observasi, Observasi yang dilakukan penulis adalah mengamati secara langsung data yang diperoleh.

- Analisis perangkat lunak, Kegiatan analisis alat dan system perangkat lunak meliputi analisis spesifikasi perangkat lunak yang akan digunakan sebagai alat bantu penelitian.

- Perancangan Perangkat Lunak, Perancangan perangkat lunak meliputi perancangan alat dan perancangann antarmuka dari hasil analisis. 
- Implementasi Perangkat Lunak, Implementasi dari hasil analisis dan perancangan perangkat lunak.

- Pengujian Perangkat Lunak, Pengujian terhadap perangkat lunak yang telah diimplementasikan.

\section{Tinjauan Pustaka}

\subsection{Algoritma K-Means Clustering}

Clustering mengacu pada pengelompokkan data, observasi atau kasus berdasar kemiripan objek yang diteliti (Muningsih \& Kiswati, 2015). Sebuah cluster adalah suatu kumpulan data yang mirip dengan lainnya atau ketidakmiripan data pada kelompok lain (Larose, 2004). Clustering dijelaskan oleh (Xu \& Wunsch, 2009) diartikan dengan membagi objek data (bentuk, entitas, contoh, ketaatan, unit) ke dalam beberapa jumlah kelompok (grup, bagian atau kategori). Sedangkan tujuan proses clustering dijelaskan oleh Agusta (2007) yaitu untuk meminimalkan terjadinya objective function yang diset dalam proses clustering, yang pada umumnya digunakan untuk meminimalisasikan variasi dalam suatu cluster dan memaksimalkan variasi antar cluster.

Algoritma K-Means adalah metode yang termasuk dalam algoritma clustering berbasis jarak yang membagi data ke dalam sejumlah cluster dan algoritma ini hanya bekerja pada atribut numerik . Pengelompokan data dengan metode K-Means dilakukan dengan dengan algoritma :

a. Tentukan jumlah kelompok

b. Alokasikan data ke dalam kelompok secara acak

c. Hitung pusat kelompok (centroid rata-rata) dari data yang ada di masing-masing kelompok. Lokasi centroid setiap kelompok diambil dari rata - rata (mean) semua nilai data setiap fiturnya. Jika $M$ menyatakan jumlah data dalams sebuah kelompok, i menyatakan fitur ke-i dalam sebuah kelompok, dan menyatakan dimensi data, maka persamaan untuk menghitung centroid fitur ke-i digunakan persamaan 1 .

$$
C i=\frac{1}{M} \sum_{J=1}^{M} X j
$$

d. Alokasikan masing-masing data ke centroid/rata terdekat . Ada beberapa cara yang dapat dilakukan ke pusat kelompok, diantaranya adalah Euclidean . Pengukuran jarak pada ruang jarak (distance space) Eucilidean dapat dicari menggunakan persamaan 2.

$$
d=\sqrt{\left(x_{1}-x_{2}\right)^{2}+\left(y_{1}-y_{2}\right)^{2}}
$$

Pengalokasian kembali data ke dalam masing-masing kelompok dalam metode K-Means didasarkan pada perbandingan jarak antara data dengan centroid setiap kelompok yang ada . Data dialokasikan ulang secara tegas ke kelompok yang mempunyai centroid dengan data tersebut dapat di gunakan persamaan 3 di bawah ini

$a_{i l}= \begin{cases}1 & d=\min \left\{D\left(X_{i 9} C 1\right\}\right. \\ 0 & \text { lainnya }\end{cases}$

$a_{i l}$ adalah nilai keanggotaan titik xi ke pusat kelompok $\mathrm{c} 1, \mathrm{~d}$ adalah jarak terpendek dari data xi ke K kelompok setelah dibandingkan dan c1 adalah centroid (pusat kelompok) ke 1. Fungsi objektif yang digunakan untuk metode K-means ditentukan berdasarkan jarak dan nilai keanggotaan data dalam kelompok. Fungsi objektif dapat ditentukan menggunakan persamaan 4

$$
J=\sum_{i=1}^{n} \sum_{l=1}^{k} a_{i c} D\left(x_{i} c_{1}\right)^{2}
$$

$\mathrm{n}$ adalah jumlah data, $\mathrm{k}$ adalah jumlah kelompok, ai1 adalah nilai kanggotaan titik data xi ke kelompok $\mathrm{c} 1$ yang diikuti . a mempunyai nilai 0 atau 1 . Apabila data merupakan anggota suatu kelompok, nilai ai $1=1$ jika tidak, nilai ai $1=0$. 
Kembali ke langkah 3, apabila masih ada data yang berpindah kelompok atau apabila ada perubahan nilai centroid di atas nilai pada fungsi objektif yang digunakan masih di atas nilai ambang yang ditentukan (Dhuhita, 2015).

\subsection{MQTT}

MQTT atau Message Queuing Telemetry Transport merupakan protokol transport dengan sifat clientserverpublish / subscribe. MQTT merupakan protokol transport dengan karakteristik sederhana, terbuka dan ringan yang dirancang agar mudakh diimplementasikan. Sehingga MQTT dapat digunakan di banyak situasi, termasuk penggunanya dalam komunikasi machine-to-machine (M2M) dan Internet of Things (IoT). Protokol MQTT berjalan dengan menggunakan TC/IP. Sehingga protokol ini membutuhkan transportasi guna menjalankan perintah MQTT, bytestream dari client to server atau server to client.

\subsection{IoT (Internet of Things)}

Internet of Things (IoT) merupakan sebuah konsep yang bertujuan untuk memperluas manfaat dari konektivitas internet yang tersambung secara terus menerus (Jansen, 2013). Suatu benda dikatakan IoT apabila terdapat pada suatu benda elektronik, atau peralatan apa saja yang tersambung ke suatu jaringan lokal dan global melalui sensor yang tertanam dan selalu aktif. Cara kerja IoT yaitu dengan memanfaatkan sebuah argumentasi pemrograman yang setiap perintah dari suatu argument menghasilkan sebuah interaksi dan komunikasi antara sesama mesin yang terhubung secara otomatis dan yang menjadi media penghubung antara perangkat tersebut adalah internet (Jansen, 2013).

Internet of Things memiliki potensi untuk mengubah dunia seperti pernah dilakukan oleh internet, bahkan mungkin lebih baik (Ashton, 2009).

IoT terdiri atas komponen - komponen :
a. Platform Hardware
b. Gateway
c. Software

Layanan Cloud (berjalan di Cloud untuk keperluan pengumpulan data dan analisa).

\subsection{Platform Node-Red}

Node-RED adalah tool dari Node.js open-source yang bertujuan untuk menyederhanakan koneksi antara perangkat IoT (Internet of Things) dan layanan web. Ini untuk menggabungkan konsep aliran untuk perangkat IoT dan data yang memungkinkan interaksi yang kompleks antara objek dan layanan. Aliran tersebut dapat dipublikasikan di situs web Node-RED untuk dibagikan. Node-RED adalah ciptaan IBM Emerging Technology. Beberapa layanan berbasis cloud seperti FRED9 menyediakan front-end untuk Node-RED dan lainnya, mengintegrasikan Node-RED ke platform mereka sendiri (mis. WotKit) untuk nilai tambah (Mineraud, Mazhelis, Su, \& Tarkoma, 2016).

Sedangkan menurut Blackstock (2015) "Node-RED adalah alat berbasis web untuk menghubungkan perangkat-perangkat keras dan API. Ini juga menyediakan editor alitan berbasis browser. Ini diimplementasikan dalam JavaScript menggunakan kerangka kerja Node.js, mengambil keuntungan dari model acara bawaan Node dan dukungan asli untuk JavaScript pada editor klien dan server."

\subsection{Nodemcu ESP8266}

Nodemcu adalah Open-source firmware dan pengembangan kit yang membantu untuk membuat prototipe produk IoT (Internet of Things) dalam beberapa baris skrip Lua nodemcu adalah sebuah platform open-source IoT (Internet of Things). Nodemcu menggunakan Lua sebagai bahasa scripting. Hal ini didasarkan para proyek Elua dan dibuat di atas ESP8266 SDK 1.4. Menggunakan banyak proyek open-source, seperti lua-cjson. Ini mencakup firmware yang berjalan pada Wi-Fi SoC ESP8266 dan perangkat keras yang di dasarkan pada ESP-12 Modul (Sambudi, 2014).

\subsection{Sensor pH Tanah}

Sensor $p H$ Tanah merupakan sensor pendeteksi tingkat keasaman (acid) atau kebasaan (alkali) tanah. Skala $p H$ yang dapat diukur oleh sensor $p H$ Tanah ini memiliki range 3.5 hingga 8. Sensor ini 
dapat langsung disambungkan dengan pin analog Arduino maupun pin analog mikrokontroller lainnya, tanpa harus memakai modul penguat tambahan (Meivaldi, 2018).

Tabel 2.1 Pin sensor

\begin{tabular}{|l|l|l|}
\hline PIN & Warna Kabel & Deskripsi \\
\hline Output & Hitam & Output ke pin nodemcu \\
\hline Gnd & Putih & GND nodemcu \\
\hline
\end{tabular}

\subsection{Sensor Kelembaban Tanah (Soil Moisture)}

Soil Moisture FC-28 adalah sensor kelembaban yang dapat mendeteksi kelembaban dalam tanah (Caesar, Isnawaty, \& Aksara, 2016). Sensor ini terdiri dua probe untuk melewatkan arus melalui tanah, kemudian membaca resistansinya untuk mendapatkan nilai tingkat kelembaban. Semakin banyak air membuat tanah lebih mudah menghantarkan listrik (resistansi kecil), sedangkan tanah yang kering sulit menghantarkan listrik (resistansi besar). Soil Moisture Sensor FC-28 memiliki spesifikasi tegangan input sebesar $3.3 \mathrm{~V}$ atau $5 \mathrm{~V}$, tegangan output sebesar $0-4.2 \mathrm{~V}$, arus sebesar $35 \mathrm{~mA}$ dan memiliki value range ADC sebesar 1024 bit mulai dari 0 - 1023 bit (Saputro, Suseno, \& Widodo, 2017).

\section{Analisa}

\subsection{Analisa Kebutuhan}

Pada analisa kebutuhan sistem membahas beberapa kebutuhan dan persyaratan terkait dengan input dan proses. Kebutuhan atau persyaratan ini diperoleh melalui Pengambilan data tanah dari 30 Daerah di Kabupaten Subang dengan 3 Zona yang berbeda, yaitu Zona Dataran Tinggi, Sedang dan Rendah. Dimana data yang sudah terkumpul ini akan diolah oleh penulis dengan melakukan teknik clustering algoritma $K$-means.

Tabel 3.1 Tabel data awal

\begin{tabular}{|c|l|c|c|c|}
\hline No. & \multicolumn{1}{|c|}{ Daerah } & Kelembaban Tanah & $\mathrm{pH}$ Tanah & Suhu Udara \\
\hline 1 & BINONG & 765 & 6,09 & 32,2284 \\
\hline 2 & PAMANUKAN & 808 & 6,45 & 34,2221 \\
\hline 3 & PONDOKBALI & 711 & 5,08 & 33,1357 \\
\hline 4 & TAMBAKDAHAN & 925 & 7,39 & 32,181 \\
\hline 5 & CICADAS & 925 & 7,39 & 32,6 \\
\hline$\cdot$ & $\cdot$ & $\cdot$ & $\cdot$ & $\cdot$ \\
$\cdot$ & $\cdot$ & $\cdot$ & $\cdot$ & $\cdot$ \\
\hline & $\cdot$ & $\cdot$ & $\cdot$ & $\cdot$ \\
\hline 26 & JALANCAGAK & 706 & 7,39 & 31,09 \\
\hline 27 & CIKAUM & 705 & 6,48 & 32,06 \\
\hline 28 & CIJAMBE & 708 & 7,39 & 31,9364 \\
\hline 29 & CISALAK & 709 & 6,36 & 30,05 \\
\hline 30 & SERANGPANJANG & 689 & 5,31 & 30,01 \\
\hline
\end{tabular}

Data keluaran yang diperoleh dari proses sistem clustering adalah pengelompokan tiap data disertai total cluster tiap iterasi nantinya.

\subsection{Analisa Sistem}

Urutan proses clustering dengan algoritma K-means untuk dapat melakukan pengelompokan data menjadi beberapa cluster adalah sebagai berikut :

a. Tentukan nilai K sebagai jumlah cluster yang diinginkan. Dalam penelitian ini data- data yang ada akan dikelompokan menjadi tiga cluster. 
b. Tentukan titik pusat awal dari setiap cluster. Dalam penelitian ini titik pusat awal ditentukan dari tempat study kasus yaitu binong \& pamanukan . Dapat dilihat di Tabel 3.2 :

Tabel 3.2 Titik pusat awal setiap cluster

\begin{tabular}{|c|c|c|c|c|}
\hline Titik Pusat Awal & Daerah & Kelembaban Tanah & $\mathrm{pH}$ Tanah & Suhu Udara \\
\hline Centroid 1 & Binong & 765 & 6,09 & 3,2221 \\
\hline Centroid 2 & Pamanukan & 808 & 6,45 & 3,2284 \\
\hline
\end{tabular}

c. Menghitung jarak setiap data ke titik pusat centroid awal antara objek ke centroid akhir dengan perhitungan jarak Eucilidean.

d. Tempatkan setiap data pada cluster. Dalam penelitian ini digunakan metode hard $k$ means untuk mengalokasikan setiap data ke dalam suatu cluster, sehingga data akan dimasukan dalam suatu cluster yang memiliki jarak paling dekat dengan titik pusat dari setiap cluster. Untuk mengetahui cluster mana yang paling dekat dengan data, maka perlu dihitung jarak setiap data dengan titik pusat setiap cluster.

Persamaan 1 menggunakan rumus 2.2 karena atribut yang digunakan berjumlah 2 . Sebagai contoh, akan dihitung jarak dari data daerah pertama ke titik pusat centroid pertama dengan persamaan :

$$
\begin{aligned}
& \begin{aligned}
d(1,1) & =\sqrt{(808-765)^{2}+(6,45-6,09)^{2}+(34,2221-32,2284)^{2}} \\
& =\sqrt{1849+0,1296+3,9748}
\end{aligned} \\
& d(1,1)=43,047699125505
\end{aligned}
$$

Dari hasil perhitungan di atas didapatkan hasil bahwa jarak data daerah pertama dengan titik centroid pertama adalah 43,047699125505.

Jarak dari data daerah pertama ke titik pusat centroid kedua dengan persamaan berikut :

$$
\begin{aligned}
& d(1,2)=\sqrt{(808-808)^{2}+(6,45-6,45)^{2}+(34,2221-34,2221)^{2}} \\
& \mathrm{~d}(1,2)=0 \\
& =\sqrt{0+0}
\end{aligned}
$$

Dari hasil perhitungan di atas didapatkan hasil bahwa jarak data daerah pertama dengan titik centroid kedua adalah 0.

Jarak dari data daerah pertama ke titik pusat centroid ketiga dengan persamaan berikut :

$$
\begin{aligned}
d(1,3) & =\sqrt{(808-711)^{2}+(6,45-5,08)^{2}+(34,2221-33,1357)^{2}} \\
& =\sqrt{9409+1,8769+1,18026} \\
d(1,3) & =97,0157572768465
\end{aligned}
$$

Dari hasil perhitungan di atas didapatkan hasil bahwa jarak data daerah pertama dengan titik centroid ketiga adalah 97,0157572768465.

Berdasarkan hasil ketiga perhitungan di atas dapat disimpulkan bahwa jarak data daerah yang paling dekat adalah ke titik pusat centroid ke 2, sehingga daerah pertama dimasukan ke dalam cluster ke 2 .

Hasil perhitungan dari iterasi satu sampai iterasi terakhir selengkapnya untuk 30 data dapat di lihat pada Tabel 3.3 :

Tabel 3.3 Hasil perhitungan iterasi 1

\begin{tabular}{|l|l|l|l|l|l|l|l|}
\hline No. & Daerah & Rh Tanah & $\mathrm{pH}$ Tanah & Suhu Udara & $\mathrm{C} 1$ & $\mathrm{C} 2$ & $\mathrm{nk}$ \\
\hline
\end{tabular}




\begin{tabular}{|c|l|c|c|c|r|r|r|}
\hline No. & \multicolumn{1}{|c|}{ Daerah } & Rh Tanah & pH Tanah & Suhu Udara & \multicolumn{1}{c|}{ C1 } & \multicolumn{1}{c|}{ C2 } & nk \\
\hline 1 & BINONG & 765 & 6,09 & 32,2284 & \multicolumn{1}{c|}{0} & 43,0477 & $\mathrm{C} 1$ \\
\hline 2 & PAMANUKAN & 808 & 6,45 & 34,2221 & 43,0477 & 0 & $\mathrm{C} 2$ \\
\hline 3 & PONDOKBALI & 711 & 5,08 & 33,1357 & 54,01706 & 97,01576 & $\mathrm{C} 1$ \\
\hline 4 & TAMBAKDAHAN & 925 & 7,39 & 32,181 & 160,0053 & 117,0216 & $\mathrm{C} 2$ \\
\hline 5 & CICADAS & 925 & 7,39 & 32,6 & 160,0057 & 117,015 & $\mathrm{C} 2$ \\
\hline 6 & BLANAKAN & 672 & 6,42 & 32,3167 & 93,00063 & 136,0134 & $\mathrm{C} 1$ \\
\hline 7 & PATOKBEUSI & 611 & 6,28 & 33,4 & 154,0046 & 197,0018 & $\mathrm{C} 1$ \\
\hline 8 & LEGONKULON & 900 & 5,72 & 34,08 & 135,0132 & 92,00301 & $\mathrm{C} 2$ \\
\hline 9 & PAGADEN & 900 & 7,26 & 32,2 & 135,0051 & 92,02578 & $\mathrm{C} 2$ \\
\hline 10 & RANCAUDIK & 731 & 6,30 & 32,08 & 34,00097 & 77,02994 & $\mathrm{C} 1$ \\
\hline 11 & PABUARAN & 640 & 6,82 & 33,08 & 125,005 & 168,0043 & $\mathrm{C} 1$ \\
\hline 12 & PUSAKAJAYA & 887 & 5,17 & 31,7 & 122,0046 & 79,05061 & $\mathrm{C} 2$ \\
\hline 13 & CIPUNAGARA & 725 & 5,10 & 34,05 & 40,05369 & 83,01116 & $\mathrm{C} 1$ \\
\hline 14 & CIASEM & 723 & 5,30 & 34,33 & 42,05997 & 85,00785 & $\mathrm{C} 1$ \\
\hline 15 & PURWADADI & 719 & 6,09 & 32,04 & 46,00039 & 89,02747 & $\mathrm{C} 1$ \\
\hline 16 & CIPEUNDEUY & 722 & 7,17 & 31,66 & 43,01732 & 86,04117 & $\mathrm{C} 1$ \\
\hline 17 & CURUGRENDENG & 728 & 7,10 & 31,55 & 37,02 & 80,04725 & $\mathrm{C} 1$ \\
\hline 18 & JABONG & 724 & 7,10 & 32,03 & 41,01292 & 84,03111 & $\mathrm{C} 1$ \\
\hline 19 & PALASARI & 718 & 7,16 & 30,01 & 47,06449 & 90,10131 & $\mathrm{C} 1$ \\
\hline 20 & CIATER & 755 & 7,00 & 29,04 & 10,53537 & 53,25558 & $\mathrm{C} 1$ \\
\hline 21 & KASOMALANG & 963 & 6,50 & 30,06 & 198,0123 & 155,0559 & $\mathrm{C} 2$ \\
\hline 22 & KALIJATI & 743 & 5,15 & 31,7673 & 22,0249 & 65,05933 & $\mathrm{C} 1$ \\
\hline 23 & CIBOGO & 712 & 6,37 & 31,45 & 53,00644 & 96,04005 & $\mathrm{C} 1$ \\
\hline 24 & DAWUAN & 710 & 7,37 & 31,44 & 55,02046 & 98,04377 & $\mathrm{C} 1$ \\
\hline 25 & SAGALAHERANG & 707 & 6,48 & 30,03 & 58,04296 & 101,087 & $\mathrm{C} 1$ \\
\hline 26 & JALANCAGAK & 706 & 7,39 & 31,09 & 59,0253 & 102,0524 & $\mathrm{C} 1$ \\
\hline 27 & CIKAUM & 705 & 6,48 & 32,06 & 60,0015 & 103,0227 & $\mathrm{C} 1$ \\
\hline 28 & CIJAMBE & 708 & 7,39 & 31,9364 & 57,01557 & 100,0305 & $\mathrm{C} 1$ \\
\hline 29 & CISALAK & 709 & 6,36 & 30,05 & 56,043 & 99,08791 & $\mathrm{C} 1$ \\
\hline 30 & SERANGPANJANG & 689 & 5,31 & 30,01 & 76,03637 & 119,08 & $\mathrm{C} 1$ \\
\hline
\end{tabular}

Dengan nilai BCV dan WCV seperti pada tabel 3.7.

Tabel 3.4 Nilai BCV dan WCV

\begin{tabular}{|l|c|}
\hline BCV & 43,0480 \\
\hline WCV & 168344,6 \\
\hline Rasio & 0,000256 \\
\hline
\end{tabular}

\subsection{Model Proses}

\subsubsection{ERD (Entity Relationship Diagram)}

Entity Relationship Diagram merupakan rancangan database dari suatu system. Penjelasan penggambaran entity relationship diagram seperti Gambar 3.13 Dimana Implementasi Algoritma K-Means untuk pengklasteran Tanah di Daerah Subang berdasarkan $p H$, Kelembaban Tanah dan Suhu berbasis IoT (Internet of Things) menggunakan Platform Node-Red sebagai berikut:

1. Entitas tbl_jadi : Entitas tbl_jadi mempunyai atribut id_jadi, nm_daerah, kelembaban, phtanah, suhu dan waktu yang dimana berelasi dengan entitas centroid_temp, dimana primary key id_jadi table tbl_jadi dan foreign key id_jadi table centroid_temp. 
2. Entitas tbl_sensor : Entitas tbl_sensor mempunyai atribut id_sensor, nm_daerah, kelembaban, phtanah, suhu dan waktu.

3. Entitas tbl_daerah: Entitas tbl_daerah mempunyai atribut id_daerah dan nm_daerah.

4. Entitas tbl_view : Entitas tbl_view mempunyai atribut id dan nm_view.

Entitas hasil_centroid : Entitas hasil_centroid mempunyai atribut nomor, c1a, c1b, c2a, c2b.

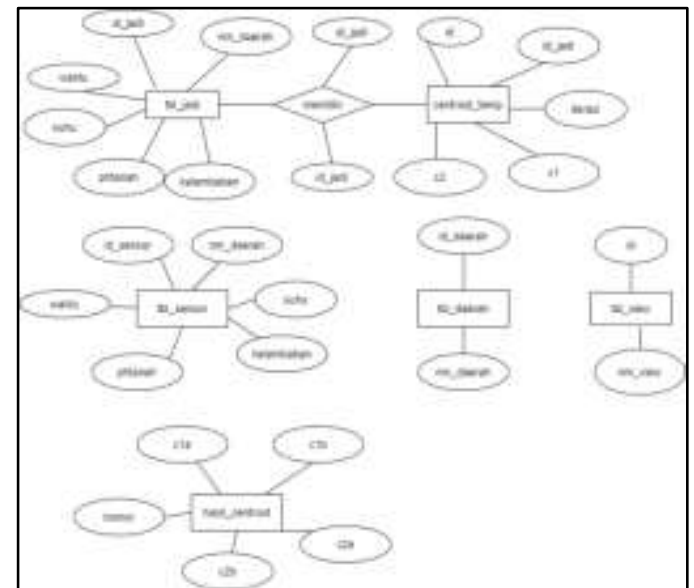

Gambar 3.13 ERD (Entity Relationship Diagram)

\section{4. $\quad$ Flow Node-Red}

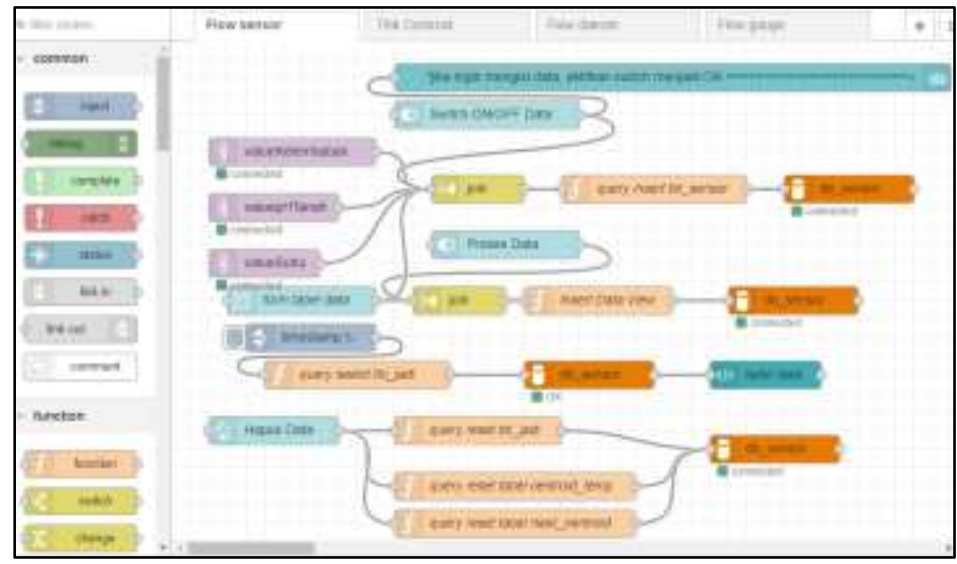

Gambar 3.14 Flow input data objek

Flow node-red adalah alur kerja dari sebuah sistem yang dibuat di dalam platform node-red, dimana didalamnya terdapat nodes input, output dan function. Pada gambar 3.14 ada 9 jenis nodes yaitu mqtt input, ui_text, switch, join, function, mysql, ui_form, inject timestamp, ui_template dan ui_button.

\subsection{Skema Alat}

Perancangan Mikrokontroler adalah schema instalasi antara sensor kelembaban tanah (soil moisture), sensor $\mathrm{pH}$ tanah, board nodemcu esp8266 dan board arduino uno penulis menggambar schema mikrokontroler ini menggunakan 2 software yaitu fritzing dan adobe xd, seperti pada gambar 3.18 sebagai berikut : 


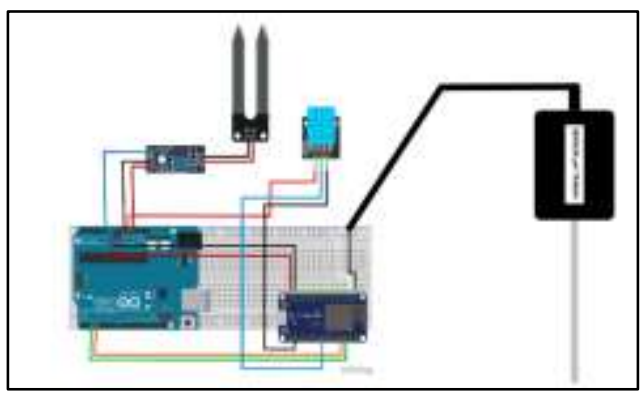

Gambar 3.18 Skema Alat.

Penjelasan gambar 3.18 yaitu sensor $p H$ tanah memiliki 2 kabel berwarna hitam dan putih, untuk kabel putih disambungkan ke lubang breadboard yang tersambung dengan pin gnd pada nodemcu dan kabel hitam disambungkan ke lubang breadboard yang tersambung dengan pin AO/pin analog. Pada sensor kelembaban tanah memiliki modul dengan pin analog, gnd dan vcc. Untuk pin analog disambungkan ke pin $A O$ pada arduino uno, pin gnd kelembaban tanah disambungkan pada pin gnd pada arduino uno, pin vcc pada kelembaban tanah disambungkan pada pin $3.3 \mathrm{v}$ pada arduino uno. Sedangkan untuk kabel berwarna hijau dan orange menyambungkan pin digital D2/D3 pada nodemcu dengan pin digital $2 / 3$ pada arduino uno untuk menyambungkan kedua board mikrokontroler. Kabel merah pada sensor Dht11 di sambungkan pada tegangan 5v di arduino, dan kabel biru d pasang pada pin 05 pada nodemcu, sedangkan kabel hitam di pasang pada gnd.

\section{Hasil dan Pembahasan}

\subsection{Implementasi Antarmuka Pengujian Data}

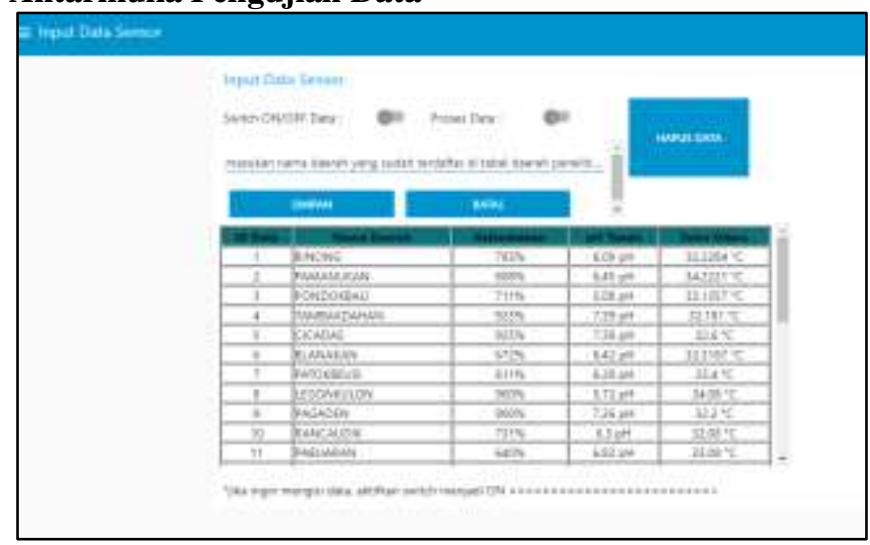

Gambar 4.1 Data Objek untuk data penelitian

Gambar 4.19 adalah data objek untuk data pengujian. Dimana penulis sudah mengambil data tersebut ke 3 zona yang berbeda di Kabupaten Subang diantaranya zona dataran tinggi, dan zona dataran rendah. Data diambil dari 30 tempat yang berbeda dengan cara pengambilan data langsung di lapangan atau mengambil sampel tanahnya untuk diteliti di rumah.

\subsection{Implementasi Pengujian Alat}

Implementasi pengujian alat merupakan gambaran dari pengujian alat yang sudah penulis uji tingkat kelayakan dan tingkat ke akuratan nya. 


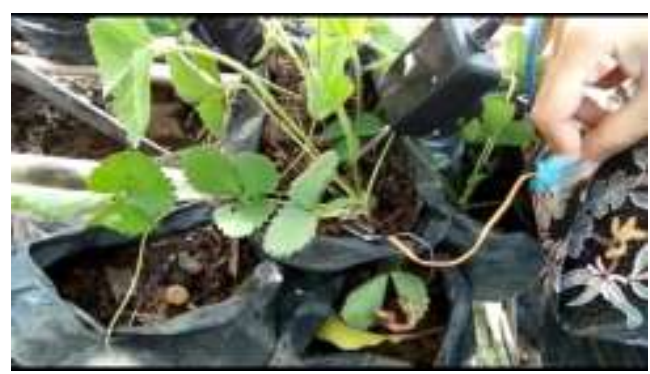

Gambar 4.2 Pengujian alat sensor pH, kelembaban tanah dan suhu udara

Pada gambar 4.20 penulis mengambil data $\mathrm{pH}$, kelembaban tanah dan suhu udara dari tanah sample yang diambil dari beberapa daerah di Kabupaten Subang untuk diinputkan ke dalam database sistem yang sudah disiapkan.

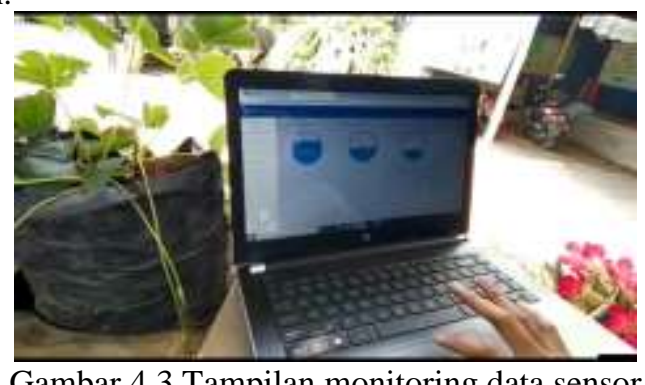

Gambar 4.3 Tampilan monitoring data sensor

Pada gambar 4.21 adalah monitoring data yang dihasilkan oleh sensor secara realtime pada platform node-red berupa gauge level dan chart.

\subsection{Tabel Hasil Pengujian Alat}

Tabel hasil pengujian alat merupakan record sistem untuk menguji apakah alat yang penulis buat berjalan dengan baik tanpa error atau tidak.

Tabel 4.1 Tabel hasil pengujian alat

\begin{tabular}{|l|l|l|}
\hline No. & Nama Proses & Hasil Pengujian \\
\hline 1 & Koneksi nodemcu ke access point & Ya \\
\hline 2 & Koneksi pc (personal computer) ke access point & Ya \\
\hline 3 & Koneksi nodemcu ke $p c$ (personal computer) & Ya \\
\hline 4 & Pengambilan data $p H$ tanah & Ya \\
\hline 5 & Pengambilang data suhu udara & Ya \\
\hline 6 & Pengambilan data kelembaban tanah & Ya \\
\hline 7 & Monitoring data dari sensor & Ya \\
\hline
\end{tabular}

\subsection{Tabel Hasil Pengujian Sistem}

Tabel ini merupakan record sistem untuk menguji apakah sistem yang penulis buat berjalan dengan baik tanpa error atau tidak.

Tabel 4.2Tabel hasil pengujian sistem

\begin{tabular}{|l|l|l|}
\hline No. & Nama Halaman dan Proses & Hasil Pengujian \\
\hline 1 & Halaman Utama/ Halaman Input Data & Ya \\
\hline 2 & Halaman Data Sensor/Manual Input Data Sensor & Ya \\
\hline 3 & Halaman Data Daerah/CRUD Tabel Daerah & Ya \\
\hline 5 & Halaman Hitung Data/Perhitungan Metode & Ya \\
\hline 6 & Halaman Hapus Semua View & Ya \\
\hline
\end{tabular}




\begin{tabular}{|l|l|l|}
\hline No. & Nama Halaman dan Proses & Hasil Pengujian \\
\hline 7 & Input data sensor & Ya \\
\hline 8 & Input, edit dan hapus manual data sensor & Ya \\
\hline 9 & Edit dan hapus data daerah & Ya \\
\hline 11 & Hitung data dengan metode & Ya \\
\hline 12 & Hapus semua view & Ya \\
\hline
\end{tabular}

\section{Simpulan}

Hasil dari penelitian ini dapat disimpulkan yaitu

1. Alat yang penulis buat bisa dipakai untuk membantu Klasterisasi kadar $p H$, kelembaban, dan suhu udaranya untuk rujukan pihak terkait dalam merekomendasikan daerah yang baik untuk budidaya Strawberry.

2. Algoritma K-means Clustering mampu mengklasterisasi kelayakan daerah untuk budidaya Strawberry.

\section{Pustaka}

Aryuni, M. (2018, Juli 17). Binus University. Diambil kembali dari Binus University: https://sis.binus.ac.id/2016/12/15/tahap-tahap-data-mining/

Ashton, K. (2009). Internet of Things.

Budiharto, W. (2010). Robotika - Teori dan Implementasinya. Yogyakarta: Andi.

Caesar, Y. P., Isnawaty, \& Aksara, L. M. (2016). Rancangan Bangun Prototype System Monitoring Kelembaban Tanah Melalui SMS Berdasarkan Hasil Penyiraman Tanaman "Studi Kasus Tanaman Cabai dan Tomat". Semantik, 97-110.

Dhuhita, W. M. (2015). Clustering Menggunakan Metode K-means Untuk Menentukan Status Gizi Balita. Jurnal Informatika, 14.

Fatoni, A., \& Rendra, D. B. (2014). Perancangan Prototype Sistem Kendali Lampu Menggunakan Handphone Android Berbasis Arduino. Jurnal PROSISKO, 23-29.

Hikmatullah, Tafakresnanto, C., Sholeh, Budiman, C., Muslihat, L., S, K., . . Sudiarto. (2015). Atlas Peta Pengembangan Kawasan Padi Kabupaten Subang, Provinsi Jawa Barat. Kementrian Pertanian, 8 .

Jansen, C. (2013). Internet of Things (IoT). Diambil kembali dari Internet of Things (IoT): https://www.techopedia.com/definition/28247/internet-of-things-iot

Larose, D. T. (2004). Discovering Knowledge in Data : An Introduction to Data Mining. New Jersey: John Wiley \& Son, Inc.

Meivaldi, R. (2018). Sistem Pengecekan pH Tanah Otomatis Menggunakan Sensor pH Probe Berbasis Android dengan Algoritma Binary Search.

Mineraud, J., Mazhelis, O., Su, X., \& Tarkoma, S. (2016). A Gap Analysis of Internet-of-Things Platform.

Muningsih, E., \& Kiswati, S. (2015). Penerapan Metode K-means untuk Clustering Produk Online Shop dalam Penentuan Stok Barang. Jurnal Bianglala Informatika, 11.

Rahayu, W. (2017). Kajian Etnobotani Potensi Tanaman Obat di Desa Buniara Kecamatan Tanjungsiang Kabupaten Subang.

Riadi, M. (2018, 04 30). Kajian Pustaka. Diambil kembali dari Kajian Pustaka: https://www.kajianpustaka.com/2017/09/data-mining.html

Sambudi, E. A. (2014). Purwarupa Pemantau Debit Air PDAM Menggunakan Sensor Aliran Air G1/2 Berbasis Arduino Uno.

Saputro, I. A., Suseno, J. E., \& Widodo, C. E. (2017). Rancang Bangun Sistem Pengaturan Kelembaban Tanah Secara Realtime Menggunakan Mikrokontroler dan Diakses di Web. Youngster Physics Journal, 40-47.

Tan, P.-N., Steinbach, M., \& Kumar, V. (2006). Introduction to Data Mining. 490.

Turban, Rainer, \& Potter. (2005). Introduction to Information Technology. 20.

Xu, R., \& Wunsch, D. C. (2009). Clustering. Canada: IEEE Press. 